\title{
An empirical investigation on ranking financial risk factors using AHP method
}

\author{
Hassan Ghodrati and Nazemi Bahareh*
}

Department of Management and Accounting, Kashan Branch, Islamic Azad University, Kashan, Iran

\section{H R O N I C L E}

Article history:

Received December 28, 2013

Accepted 10 April 2014

Available online

April 142014

Keywords:

Risk

Risk Management

Economic Risk

Ranking

AHP

\begin{abstract}
A B S T R A C T
This paper determines and ranks financial risk factors in Iranian corporations, using analytical hierarchy process (AHP). The present research includes one main question and four subquestions. Its universe population includes managers, production and financial personnel of great corporations activating in Tehran Stock Exchange, who were selected to explain importance and weight of economic risks indices. The source of great corporations recognition is the Companies Registration Organization in Tehran Province, and according to this, there are 120 corporations. The results have indicated that financing risk maintains the highest priority followed by credit risk, liquidity risk, inflation risk and exchange risk. In terms of different risks associated with financing risk, risk of profit per share has been the number one priority followed by the risk of divisional profit per share, the risk of recessionary or boom and the risk of increasing partial pay profit rate. In terms of credit risk, the risk of loan has been number one priority followed by the risk of inability of loan payment and interest payment. Liquidity risk is another risk factor where demand has been the most important factor followed by rules and regulations and inflation risk. In terms of inflation, producers price risk has been the most important factor followed by consumer price risk, gross domestic product and producers price risk. Finally, in terms of different factors influencing exchange risk, export related issues are considered as the most important factors.
\end{abstract}

(c) 2014 Growing Science Ltd. All rights reserved.

\section{Introduction}

One of the primary concerns on business development is to reduce any possible risk factors on big firms whose shares are also listed on stock exchange (Short, 1984; Christoffersen \& Gonçalves, 2004). There are literally various studies concentrated on risk assessment. Some newly established information technology based firms are heavily influenced by various risk factors (Licht \& Nerlinger, 1998). Pongsakdi et al. (2006), for instance, studied the financial risk aspects associated with the purchase of crude oil. They determined how to purchase and decide on the production level of various products given forecasts of demands and they examined their model using data from the Refinery owned by the Bangchak Petroleum Public Company Limited, Thailand. Many risk assessment methods are involved with

*Corresponding author.

E-mail addresses: nazemibahreh@yahoo.com (B. Nazemi) 
multiple criteria decision making techniques (Wang \& Lee, 2007; Shih et al., 2007) such as analytical hierarchy process (AHP) (Saaty, 2004), analytical network process (ANP) (Saaty, 2004), etc.

Lee et al. (2008) proposed an approach based on the fuzzy AHP (FAHP) and balanced scorecard (BSC) for assessing an information technology (IT) department in the manufacturing industry in Taiwan. The BSC concept was implemented to describe the hierarchy with four major BSC perspectives, namely financial, customer, internal business process, and learning and growth. They also used FAHP to handle vagueness and ambiguity of information.

Stoneburner et al. (2002) also provided a comprehensive method for assessing different risk components on the market. Belk and Edelshain (1997) investigated the existing evidence from empirical surveys of foreign exchange risk and its management to confirm or to reject theoretical predictions and the truth of some paradox, and suggested a rationale for its existence. Raz and Michael (2001) identified some tools, which are most widely applied and those that are associated with successful project management in general, and with project risk management. Using a questionnaire the study tried to find which tools are more likely to be applied in those organizations that report better project management performance and in those that value the contribution of risk management processes.

Cooper et al. (2014) proposed a mathematical tool to assess relative risk tolerance using Data Envelopment Analysis (DEA). Using a questionnaire in four groups including propensity, attitude, capacity, and knowledge, they surveyed over 180 individuals their responses were analyzed using the Slacks-based measure type of DEA efficiency model. They reported that the multidimensionality of risk must be taken into account for complete assessment of risk tolerance. This approach also provided some insight into the relationship between risk, its elements and other variables. Specifically, the perception of risk changes by gender as men were generally less risk averse than women. Risk attitude and knowledge scores were consistently lower for women, while there was no statistical difference in their risk capacity and propensity compared to men. The tool can also serve as a "risk calculator" for an appropriate and defensible method to reach legal compliance requirements, known as the "Know Your Client" rule, that exist for Canadian financial institutions and their advisors.

\section{The proposed method}

In this research, a fuzzy model was used, so its results is not generalizable. Therefore, random sampling was not used and the research concluding is descriptive. Our data were gathered based on expert interviewing, therefore this research plan is survey. Based on the descriptive method the aim of this research is to response following questions:

Main Question: What are the important financial risk factors and their ranks on Iranian corporations?

Sub-questions:

1. What are the financial risk factors on Iranian corporations?

2. What is the importance degree of each financial risk factors?

3. What is the rank of each risk factors Rank based on AHP results?

The statistical universe of this research includes financial and production managers as well as selected employees who work for firms operating in stock exchange. They are selected to measure the relative importance of various economic risk factors. The survey was limited to firms, which were active in city of Tehran, Iran. The sample size is calculated as follows, 


$$
n=\frac{N \times z_{\alpha / 2}^{2} \times p \times q}{\varepsilon^{2} \times(N-1)+z_{\alpha / 2}^{2} \times p \times q},
$$

where $N$ is the population size, $p=1-q$ represents the yes/no categories, $z_{\alpha / 2}$ is CDF of normal distribution and finally $\varepsilon$ is the error term. Since we have $p=0.5, z_{\alpha / 2}=1.96$ and $N=120$, the number of sample size is calculated as $n=92$. The survey has distributed 120 questionnaires and managed to collect 92 properly filled ones. The questionnaire includes 48 multiple-choice, close-ended questions where 43 questions were associated with subordinate indices and 5 questions were related to main indices. All questions were in Likert scale where 1 demonstrates the least degree of importance and 9 demonstrates the degrees of importance. The participants were asked about some demographic information and their feedback were used to rank various factors. Fig. 1 shows the hierarchy of the proposed study.

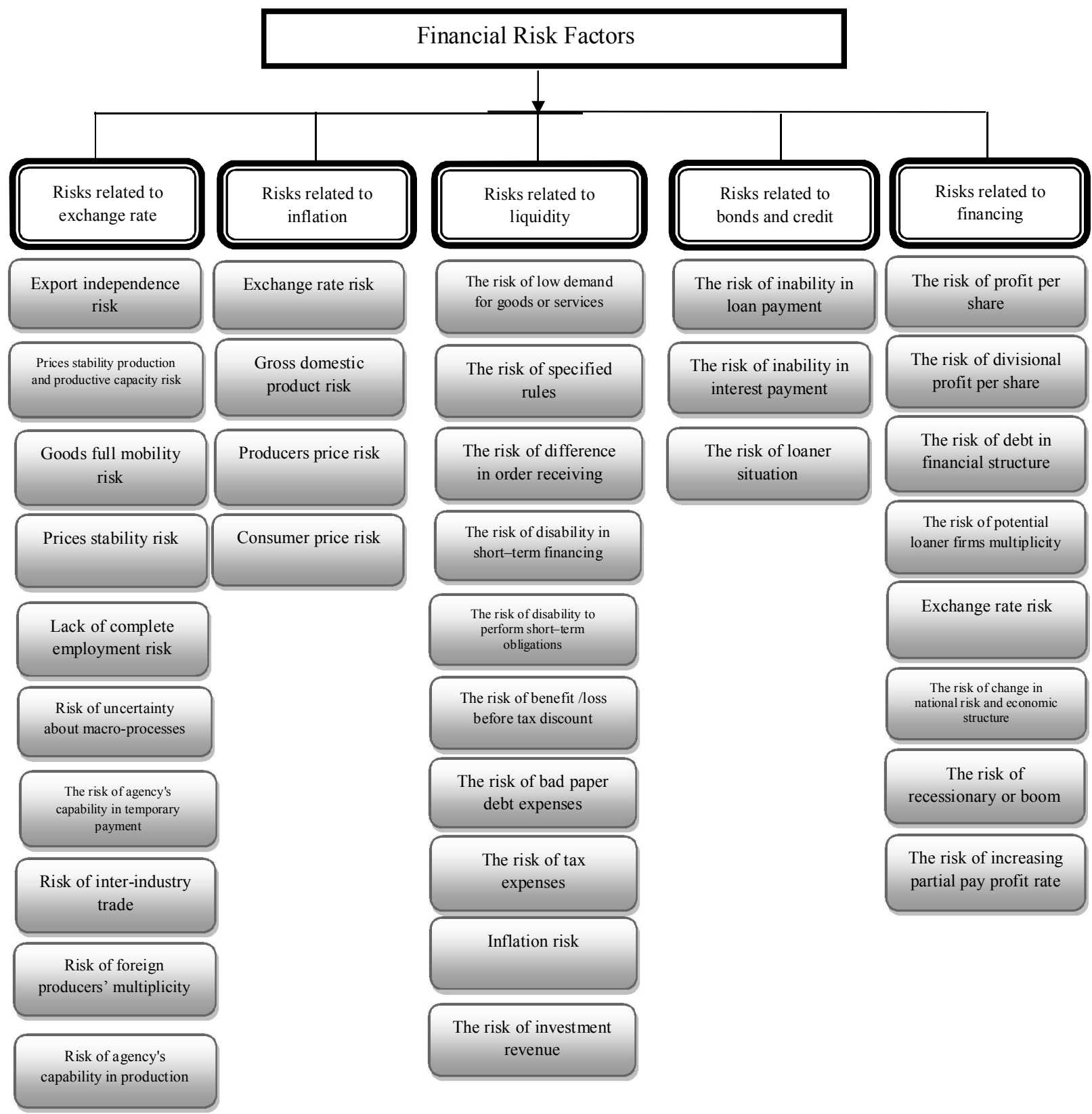

Fig. 1. Research Model 
The proposed study of this paper uses analytical hierarchy process (AHP) to rank different factors (Chang, 1996; Saaty, 2004). First, we describe the statistical community and questions responses and then we rank risk priorities based on AHP method. Fig. 2 demonstrates the summary of our statistics on people, who participated in our survey,

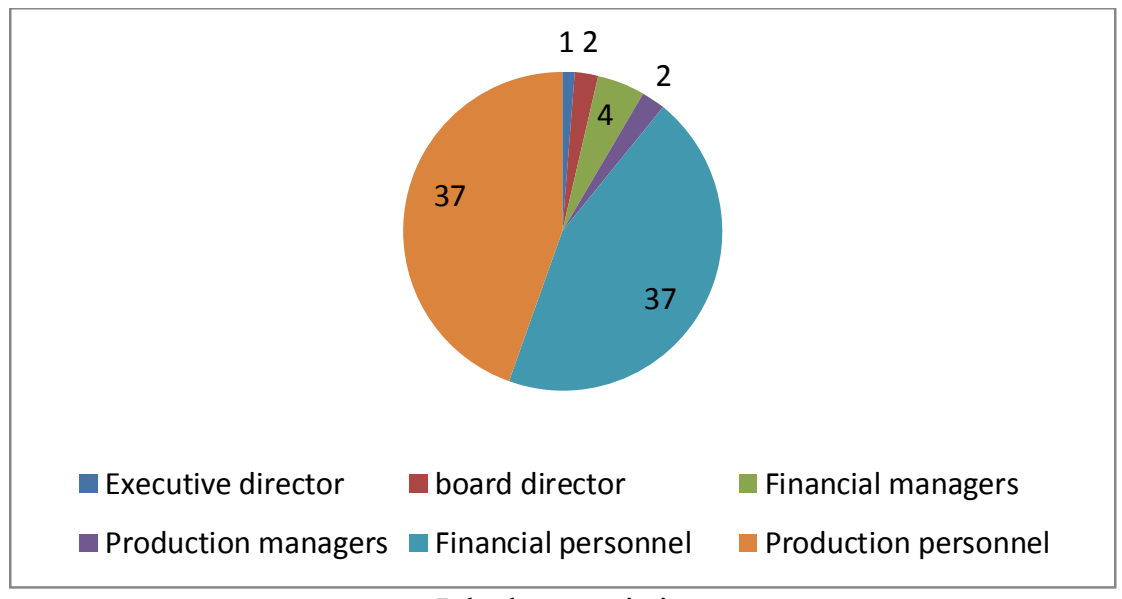

Job characteristics

Fig. 2. Personal characteristics of the participants

After reviewing global literature and extracting economic risk indices in big corporations, a questionnaire was distributed among experts for making a comment and final selection, which includes the most important economic risk indices. The statistical community was divided based on their responsibilities on different groups. Fig. 3 and Fig. 4 demonstrate the summary of participants' gender and educational backgrounds.

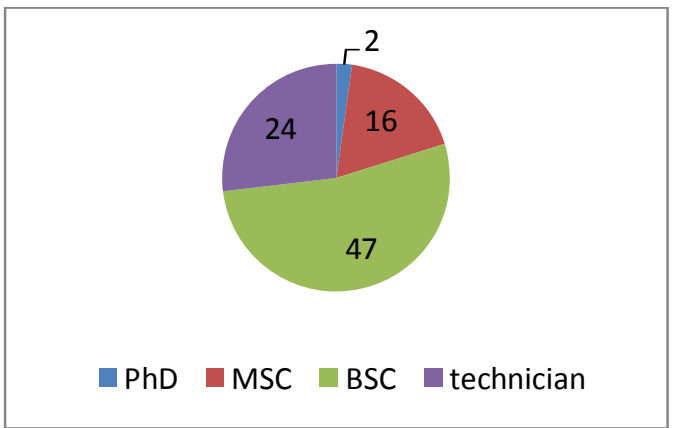

Level of education

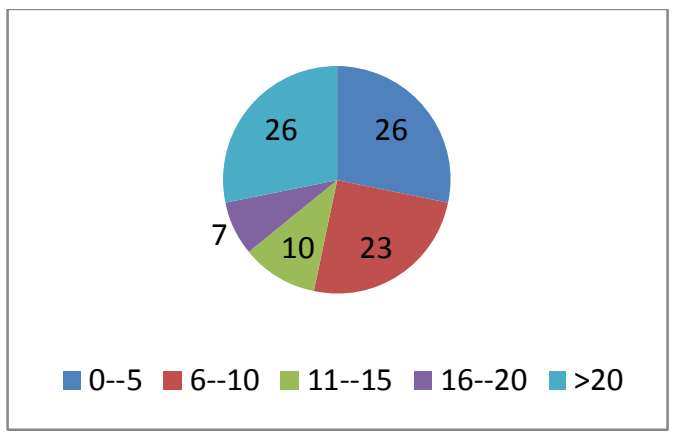

Job experience

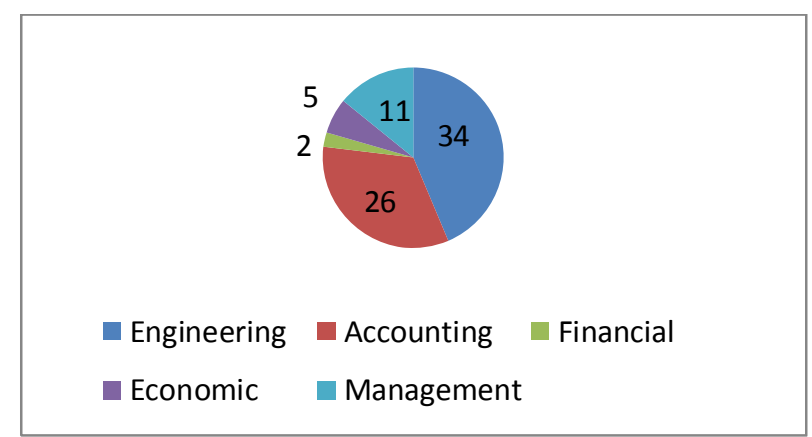

Field of education

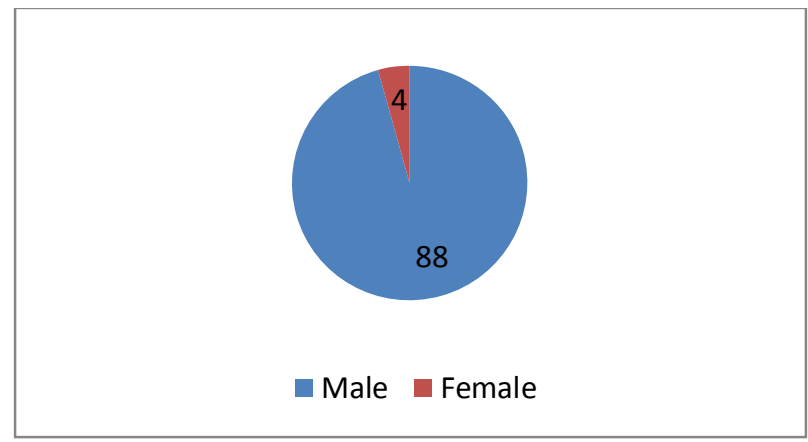

Gender

Fig. 3. Personal characteristics of the participants

As we can observe from the figures, the most frequency is related to financial and production personnel. In our survey, 95 percent of participants were male 5 percent of them were female. In 
addition, most people had at least five years of job experiences and maintained a good university background. In The risk factors were evaluated based on expert interviewing. Each factor was evaluated with a question that responded with 1-9 as factor important or effect. Table 1 demonstrates the summary of some basic statistics associated with 48 questions of the survey.

Table 1

The summary of some basic statistics

\begin{tabular}{|c|c|c|c|c|c|}
\hline Question & mean & median & Standard deviation & Skewedness & Kurtosis \\
\hline 1 & 8.21 & 8.11 & 0.9854 & -0.8554 & -0.154 \\
\hline 2 & 7.39 & 7.09 & 0.9654 & -0.587 & -0.2547 \\
\hline 3 & 8.32 & 8.47 & 0.9457 & -0.8587 & -0.5848 \\
\hline 4 & 3.214 & 3.30 & 0.8540 & -0.8658 & -0.5415 \\
\hline 5 & 7.14 & 7.74 & 0.8945 & -0.8745 & -0.51458 \\
\hline 6 & 8.21 & 8.64 & 0.4815 & -0.3580 & -0.547 \\
\hline 7 & 8.47 & 8.01 & 0.8784 & -0.8745 & -0.2154 \\
\hline 8 & 7.21 & 7.29 & 0.8895 & -0.2547 & -0.875 \\
\hline 9 & 6.54 & 6.74 & 0.5647 & -0.6587 & -0.3265 \\
\hline 10 & 8.23 & 8.94 & 0.8795 & -0.5478 & -0.5478 \\
\hline 11 & 7.74 & 7.64 & 0.5468 & -0.5478 & -0.6587 \\
\hline 12 & 6.38 & 6.11 & 0.8745 & -0.4587 & -0.22145 \\
\hline 13 & 7.10 & 7.19 & 0.8401 & -0.6985 & -0.3698 \\
\hline 14 & 2.47 & 2.41 & 0.6748 & -0.4587 & -0.2159 \\
\hline 15 & 7.41 & 7.69 & 0.564 & -0.3254 & -0.3658 \\
\hline 16 & 7.20 & 7.30 & 0.6478 & -0.7854 & -0.1547 \\
\hline 17 & 7.14 & 7.74 & 0.87 & -0.4587 & -0.369 \\
\hline 18 & 7.25 & 7.11 & 0.6587 & -0.2549 & -0.6598 \\
\hline 19 & 4.87 & 4.98 & 0.687 & -0.5478 & -0.4587 \\
\hline 20 & 7.74 & 7.47 & 0.5678 & -0.6587 & -0.6589 \\
\hline 21 & 8.32 & 8.66 & 0.567 & -0.8554 & -0.2154 \\
\hline 22 & 8.28 & 8.41 & 0.5648 & -0.8547 & -0.6985 \\
\hline 23 & 6.98 & 6.02 & 0.5674 & -0.5698 & -0.3659 \\
\hline 24 & 6.38 & 6.47 & 0.564 & -0.7854 & -0.2547 \\
\hline 25 & 3.55 & 3.03 & 0.897 & -0.5587 & -0.6985 \\
\hline 26 & 7.21 & 7.67 & 0.6587 & -0.8754 & -0.6985 \\
\hline 27 & 8.31 & 8.24 & 0.564 & -0.5874 & -0.3658 \\
\hline 28 & 8.64 & 8.60 & 0.674 & -0.906 & -0.96985 \\
\hline 29 & 7.12 & 7.07 & 0.564 & -0.965 & -0.6985 \\
\hline 30 & 7.99 & 7.54 & 0.587 & -0.879 & -0.2545 \\
\hline 31 & 7.95 & 7.64 & 0.6785 & -0.7854 & -0.5874 \\
\hline 32 & 8.31 & 8.42 & 0.5102 & -0.879 & -0.65987 \\
\hline 33 & 8.31 & 8.31 & 0.7454 & -0.8554 & -0.25487 \\
\hline 34 & 6.94 & 6.64 & 0.865 & -0.879 & -0.3658 \\
\hline 35 & 8.37 & 8.37 & 0.645 & -0.9541 & -0.32326 \\
\hline 36 & 7.23 & 7.23 & 0.685 & -0.879 & -0.1254 \\
\hline 37 & 2.60 & 2.60 & 0.658 & -0.9632 & -0.5478 \\
\hline 38 & 8.31 & 8.31 & 0.854 & -0.8554 & -0.2154 \\
\hline 39 & 7.1 & 7.1 & 0.587 & -0.879 & -0.6598 \\
\hline 40 & 8.22 & 8.22 & 0.657 & -0.8554 & -0.3658 \\
\hline 41 & 7.15 & 7.15 & 0.654 & -0.879 & -0.3154 \\
\hline 42 & 7.36 & 7.36 & 0.687 & -0.8554 & -0.956 \\
\hline 43 & 3.08 & 3.08 & 0.658 & -0.9965 & -0.5487 \\
\hline 44 & 7.98 & 7.98 & 0.849 & -0.7854 & -0.3998 \\
\hline 45 & 8.69 & 8.69 & 0.894 & -0.9854 & -0.015 \\
\hline 46 & 2.87 & 2.87 & 0.859 & -0.9658 & -0.6596 \\
\hline 47 & 6.98 & 6.98 & 0.859 & -0.154 & -0.5987 \\
\hline 48 & 7.21 & 7.21 & 0.689 & -0.587 & -0.3369 \\
\hline
\end{tabular}

As we can observe from the results of Table 1, most items maintain a mean of well above 5. Table 2 shows the propriety of five main risk factors. 
Table 2

The summary of priority of the main five risk factors

\begin{tabular}{lccccc}
\hline Measure & Financing risk & Credit risk & Liquidity risk & Inflation risk & Exchange risk \\
\hline Priority & 0.293 & 0.251 & 0.177 & 0.147 & 0.128 \\
\hline
\end{tabular}

As we can observe from the results of Table 2, financing risk maintains the highest priority followed by credit risk, liquidity risk, inflation risk and exchange risk. Table 3 shows details of our investigation on ranking risks associated with financing expenses.

\section{Table 3}

The summary of risk associated with financing expenses

\begin{tabular}{lc}
\hline Description of risk factor & Priority \\
\hline The risk of profit per share & 0.271 \\
The risk of divisional profit per share & 0.186 \\
The risk of debt in financial structure & 0.043 \\
The risk of potential loaner firms multiplicity & 0.088 \\
Exchange rate risk & 0.114 \\
The risk of change in national risk and economic structure & 0.054 \\
The risk of recessionary or boom & 0.124 \\
The risk of increasing partial pay profit rate & 0.120 \\
\hline
\end{tabular}

As we can observe from the results of Table 3, risk of profit per share is number one priority followed by the risk of divisional profit per share, the risk of recessionary or boom and the risk of increasing partial pay profit rate. Credit risk is another component and Table 4 demonstrates the summary of our ranking.

\section{Table 4}

The summary of credit risk

\begin{tabular}{lr}
\hline Description of risk factor & Priority \\
\hline The risk of inability in loan payment & 0.325 \\
The risk of inability in interest payment & 0.154 \\
The risk of loan situation & 0.494
\end{tabular}

Based on the results of Table 4, the risk of loan is number one priority followed by the risk of inability of loan payment and interest payment. The next risk factor is associated with liquidity risk and Table 5 shows details of our ranking using AHP method.

\section{Table 5}

The summary of liquidity risk

\begin{tabular}{lc}
\hline Description of risk factor & Priority \\
\hline The risk of low demand for goods or services & 0.191 \\
The risk of specified rules & 0.121 \\
The risk of difference in order receiving & 0.042 \\
The risk of disability in short-term financing & 0.035 \\
The risk of disability to perform short-term obligations & 0.16 \\
The risk of benefit /loss before tax discount & 0.078 \\
The risk of bad paper debt expenses & 0.107 \\
The risk of tax expenses & 0.098 \\
Inflation risk & 0.099 \\
The risk of investment revenue & 0.069 \\
\hline
\end{tabular}

According to the results of Table 5, demand is the most important factor followed by rules and regulations and inflation risk. Inflation is another risk component with four sub-component, which are summarized in Table 6 as follows, 
Table 6

The summary of risk factors associated with inflation

\begin{tabular}{lr}
\hline Description of risk factor & Priority \\
\hline Gross domestic product risk & 0.248 \\
Producers price risk & 0.324 \\
Producers price risk & 0.125 \\
Consumer price risk & 0.303
\end{tabular}

The results of Table 6 specify that producers price risk is the most important factor followed by consumer price risk, gross domestic product and producers price risk. Finally, exchange rate risk is the last component of the survey and Table 7 shows details of our survey.

Table 7

The summary of risk factors associated with exchange rate

\begin{tabular}{ll}
\hline Description of risk factor & Priority \\
\hline Export independence risk & 0.140 \\
Prices stability production and productive capacity risk & 0.025 \\
Goods full mobility risk & 0.036 \\
Prices stability risk & 0.104 \\
Lack of complete employment risk & 0.123 \\
Risk of uncertainty about macro-processes & 0.012 \\
The risk of agency's capability in temporary payment & 0.098 \\
Risk of inter-industry trade & 0.032 \\
Risk of foreign producers multiplicity & 0.13 \\
Risk of agency's capability in production & 0.103
\end{tabular}

In terms of different factors influencing exchange risk, export related issues are considered as the most important factors. In addition, factors associated with employment, and agency's capability in production is other important factor.

\section{Conclusion}

In this paper, we have presented an empirical investigation to rank various risk factors including financing risk, credit risk, liquidity risk, inflation risk and exchange risk using AHP method. The results have indicated that financing risk maintains the highest priority followed by credit risk, liquidity risk, inflation risk and exchange risk. In terms of different risks associated with financing risk, risk of profit per share has been the number one priority followed by the risk of divisional profit per share, the risk of recessionary or boom and the risk of increasing partial pay profit rate. In terms of credit risk, the risk of loan has been number one priority followed by the risk of inability of loan payment and interest payment. Liquidity risk is another risk factor where demand has been the most important factor followed by rules and regulations and inflation risk. In terms of inflation, producers price risk has been the most important factor followed by consumer price risk, gross domestic product and producers price risk. Finally, in terms of different factors influencing exchange risk, export related issues are considered as the most important factors.

\section{Acknowledgement}

The authors would like to thank the anonymous referees for constructive comments on earlier version of this paper.

\section{References}

Belk, P. A., \& Edelshain, D. J. (1997). Foreign exchange risk management - the paradox. Managerial Finance, 23(7), 5-24. 
Chang, D. Y. (1996). Applications of the extent analysis method on fuzzy AHP. European journal of operational research, 95(3), 649-655.

Christoffersen, P., \& Gonçalves, S. (2004). Estimation risk in financial risk management. CIRANO.

Cooper, W.W., Kingyens, A.T., Paradi, J.C. (2014). Two-stage financial risk tolerance assessment using data envelopment analysis. European Journal of Operational Research, 233(1), 273-280

Lee, A. H., Chen, W. C., \& Chang, C. J. (2008). A fuzzy AHP and BSC approach for evaluating performance of IT department in the manufacturing industry in Taiwan. Expert systems with applications, 34(1), 96-107.

Licht, G., \& Nerlinger, E. (1998). New technology-based firms in Germany: a survey of the recent evidence. Research Policy, 26(9), 1005-1022.

Pongsakdi, A., Rangsunvigit, P., Siemanond, K., \& Bagajewicz, M. J. (2006). Financial risk management in the planning of refinery operations. International Journal of Production Economics, 103(1), 64-86.

Raz, T., \& Michael, E. (2001). Use and benefits of tools for project risk management. International Journal of Project Management, 19(1), 9-17.

Saaty, T. L. (2004). Decision making - the analytic hierarchy and network processes (AHP/ANP). Journal of systems science and systems engineering,13(1), 1-35.

Shih, H. S., Shyur, H. J., \& Lee, E. S. (2007). An extension of TOPSIS for group decision making. Mathematical and Computer Modelling, 45(7), 801-813.

Short, J. F. (1984). The social fabric at risk: toward the social transformation of risk analysis. American sociological review, 49, 711-725.

Stoneburner, G., Goguen, A., \& Feringa, A. (2002). Risk management guide for information technology systems. Nist special publication, 800(30), 800-30.

Wang, Y. J., \& Lee, H. S. (2007). Generalizing TOPSIS for fuzzy multiple-criteria group decisionmaking. Computers \& Mathematics with Applications, 53(11), 1762-1772. 